\title{
The performance properties of the yarn and fabrics produced from different types of cotton
}

DOI: 10.35530/IT.070.05.1651

\section{ABSTRACT - REZUMAT}

\section{The performance properties of the yarn and fabrics produced from different types of cotton}

In this study, performance properties of single jersey knitted fabrics made from Aegean cotton, Supima cotton and Giza cotton yarns are investigated. Firstly, Uster parameters and breaking strength of the yarns were examined and then the properties of the fabrics knitted from these yarns were evaluated statistically. The significance levels of the relationship between the measured parameters were determined. Considering the results obtained with the mechanical properties of the fabrics with Uster analysis applied to these yarns, it is seen that the yarns made from Supima and Giza cotton fibers in extra long fiber category have more smooth, less hairiness, contain less neps and the fabrics knitted with these yarns have high mechanical properties.

Keywords: Supima cotton, Giza cotton, Aegean cotton, fabric, bursting strength.

Proprietățile de performanță ale firelor și tricoturilor realizate din diferite tipuri de fibre de bumbac

În cadrul acestui studiu, au fost analizate proprietățile de performanță ale tricoturilor glat realizate din fire de bumbac Aegean, de bumbac Supima și de bumbac Giza. În primul rând, au fost analizaţi parametrii Uster și rezistența la rupere a firelor și apoi au fost evaluate statistic proprietățile tricoturilor obţinute din aceste fire. Au fost calculate nivelurile de semnificație ale relației dintre parametrii determinaţi. Având în vedere rezultatele obținute prin analiza Uster, s-a concluzionat că firele realizate din fibre de bumbac Supima și de bumbac Giza, din categoria de fibre extralungi, sunt netede, au o pilozitate mai mică, conțin mai puține nopeuri, iar tricoturile obţinute din aceste fire prezintă proprietăți mecanice ridicate.

Cuvinte-cheie: bumbac Supima, bumbac Giza, bumbac Aegean, tricot, rezistență la plesnire

\section{INTRODUCTION}

Efforts for research and development activities in the textile industry, with increased demand for more comfortable, healthier and environmentally friendly products, focused on the utilisation of renewable and biodegradable resources as well as environmentally sound manufacturing processes in textiles. In this respect, new types of renewed fibers and cotton have gained importance as an alternative to traditional ones in apparel and home textile manufacturing [1]. Although there are many studies on the performance characteristics of various fabrics, but there are limited number of studies on different types of cotton.

Messiry \& Abd-Ellatif [2] studied the quality of the Egyptian cotton varieties in terms of morphological examination, strength of single fibers and other tuft properties determined by HVI.

Ozcelık et al. [3] studied on the structural properties of viscose, modal and lyocell fibers and yarns. Besides, they determined the influence of structural characteristics of the fibers on the performance properties of knitted fabrics such as pilling, bursting strength, color efficiency and thermo physiological properties. The results show that due to the fiber structure, pilling tendency of viscose fabric is higher compared to lyocell and modal grey fabrics. Since the tensile strength of lyocell fiber is higher, fabric bursting strength of lyocell fabric is higher than the modal and viscose fabrics.

Demiroz Gun et al. [4] examined dimensional and some physical properties of plain knitted fabrics made from 50/50 bamboo/cotton blended yarns. In order to see the differences and similarities, they compared the results with those for similar fabrics woven from 50/50 conventional viscose/cotton and $50 / 50$ modal/cotton blended yarns.

Dirgar [5] examined the performance characteristics of jersey knitted fabrics made of viscose, modal, lyocell and cupro yarns. In this study, performance properties of the fabrics such as fabric weight per unit area, thickness, bursting strength, abrasion resistance, fabric stretch, porosity, air permeability and pilling were evaluated statistically and the importance levels of the relationship between the measured parameters were determined.

Ozdemir [6] investigated the effects of yarn structural parameters and sizing on the physical properties of $100 \%$ cotton carded and combed ring yarns, sized with four different sizing agents.

In this study, performance characteristics of yarn and knitted fabrics produced from Aegean cotton, extra long-fiber Supima cotton (American cotton) and 
extra-long filament Giza cotton (Egypt cotton), having different fiber length and fiber fineness, were examined.

\section{Fibers used in the study}

Aegean Cotton: The cottons produced in some districts of İzmir, Aydın, Manisa, Muğla, Denizli, Çanakkale and Bursa are called Aegean Cotton and registered by İmir Commodity Exchange in this direction. Due to the climate, soil properties and ecological conditions, Aegean cotton is much better properties in terms of the brightness and softness and yarn (twist, tensile strength) properties according to other cotton [7]

Pima and Supima Cotton: A cotton fiber must be at least $34.9 \mathrm{~mm}$ (1 $3 / 8 \mathrm{inch})$ in length to be called extra-long fiber. Supima is one of the longest cotton varieties among the extra long fibers and has an average length of $36.5 \mathrm{~mm}$ (1 7/16 inch) [8].

Pima cotton is a kind of cotton known as extra long fiber cotton. These cottons are grown in countries such as America, Peru, Spain, Australia. Supima is an organization founded in 1954 by American Pima cotton growers. American Pima cottons can be sold to licensed producers who are members of the Supima organization all over the World [7].

The long fibers and the superior strength of the Supima result in a stronger yarn. This means that the Supima fabrics are thinner (lighter) and softer than the other types of cotton. The combination of fiber fineness, length and strength provides a silky feel, luxurious shine, less hairiness and more color alternatives [8-9].

Giza Cotton: Egyptian cotton is a world-wide variety of cotton. Its quality, fiber length, and fiber properties of this cotton do not change according to years. For this reason, it is suitable for obtaining high quality spinning results. In Egypt, medium-long, long and extra-long cotton fibers used in the production of high quality textile are produced and these products are named with the name Giza and a number next to it. The staple length of Giza cotton ranges from $3.8 \mathrm{~cm}$ to $5.7 \mathrm{~cm}$ (1.5 inches to 2.25 inches). Since the fiber length is longer than the other cotton types, it is possible to produce very fine yarn counts. Giza cotton fiber is very soft, glossy and high strength. One of the features that make Giza cotton high quality is its power to absorb liquid. Thanks to this feature, it allows the dye to be absorbed much better, thus ensuring that the product maintains its color tone and vitality for a longer period of time than other cottons. Giza cotton is preferred by the world brands that appeal to luxury and high income groups. Since Egyptian cotton is more resistant and softer than other cotton species, it is slightly more expensive in price [10].

\section{MATERIAL AND METHOD}

\section{Materials}

In this study, primarily, yarns made of different cotton fibers (Aegean cotton, extra-long fibrous American cotton (Supima) and extra-long fibrous Egyptian cotton (Giza)) and fabrics knitted made of these yarns, were used. The properties of these yarns are given in table 1.

Table 1

\begin{tabular}{|l|c|c|}
\hline \multicolumn{3}{|c|}{ THE SPECIFICATIONS OF THE YARNS } \\
\hline \multicolumn{1}{|c|}{ Raw material } & Yarn ype & Yarn count \\
\hline $100 \%$ Aegean Cotton & Ring & Ne 60/1 \\
\hline $100 \%$ Giza Cotton & Ring & Ne 60/1 \\
\hline $100 \%$ Supima Cotton & Ring & Ne 60/1 \\
\hline
\end{tabular}

Then knitted fabrics were produced using these yarns. The fabrics were hydrophilized by alkali treatment prior to measurement. Before testing, all yarn and fabric samples were conditioned for 24 hours under the standard atmospheric conditions $\left(20 \pm 2^{\circ} \mathrm{C}\right.$ temperatures, $65 \% \pm 5 \%$ relative humidity).

\section{Methods}

In the first stage of the work, yarn unevenness (U\%), imperfections (IPI fault) values (thin places $(-50 \%)$, thick places $(+50 \%)$ and neps $(+140 \%))$, hairiness values and breaking elongation were determined.

Yarn evenness, hairiness and imperfections (IPI fault) values were measured by USTER Tester 5 according to ISO 16549. 10 tests were done each type of yarn and the average value was taken.

Breaking elongation of the yarns was carried out according to TS 245 EN ISO 2062. $250 \mathrm{~mm}$ measuring range were used and testing speed were 250 $\mathrm{mm} /$ minute.

In the second stage of the work, these yarns were used to produce plain singe jersey fabrics. All single jersey fabrics were manufactured at the Mesdan Lab knitting machine by using the same production settings in order to eliminate the production effects. Technical properties of knitting machine were summarized in table 2 .

Table 2

TECHNICAL PROPERTIES OF KNITTING MACHINE

\begin{tabular}{|l|c|}
\hline Number of needle & 220 \\
\hline Diameter (inch) & $33 / 4$ \\
\hline Gauge & 48 \\
\hline Knitting type & Single jersey \\
\hline Yarn tension & 38 \\
\hline Production speed (turns $/ \mathrm{m})$ & 225 \\
\hline
\end{tabular}

Then these fabrics were analyzed to determine weight per square meter, thickness, bursting strength. Thickness and weight of the fabrics were measured according to the relevant standards [11-12].

Bursting strengths of the fabrics were tested according to ISO 13938-2 with 5 repetitions using JH Truburst. 
Results were evaluated by SPSS statistical program. All test results were assessed at a confidence level of at least 95\% (at most 5\% significance level).

\section{RESULTS AND DISCUSSIONS}

\section{Findings related to Uster parameters}

Table 3 shows USTER values for the yarns used in the study.

Table 3

\begin{tabular}{|c|c|c|c|}
\hline \multicolumn{4}{|c|}{ USTER VALUES OF THE YARNS } \\
\hline Material & $\begin{array}{c}100 \% \\
\text { Aegean } \\
\text { cotton }\end{array}$ & $\begin{array}{c}100 \% \\
\text { Giza } \\
\text { cotton }\end{array}$ & $\begin{array}{l}100 \% \\
\text { Supima } \\
\text { cotton }\end{array}$ \\
\hline Um (\%) & 11.44 & 10.84 & 9.93 \\
\hline CVm (\%) & 14.47 & 13.68 & 12.55 \\
\hline $\begin{array}{l}\text { Thin places }(- \\
50 \%) / 1000 \mathrm{~m}\end{array}$ & 21.6 & 5.2 & 0.8 \\
\hline $\begin{array}{l}\text { Thick places (- } \\
50 \%) / 1000 \mathrm{~m}\end{array}$ & 68.8 & 49.4 & 30.2 \\
\hline Neps $(+140 \%) / 1000 \mathrm{~m}$ & 1651 & 6496 & 529.4 \\
\hline Hairiness $(\mathrm{H})$ & 4.77 & 4.45 & 4.1 \\
\hline
\end{tabular}

When the yarn irregularity (U\%) is examined, it is seen that the yarns produced from Supima cotton fibers have the lowest value. The low CV\% means that the mass changes in the yarn are low. The yarns with a low CV\% are always preferred. The smaller the $\mathrm{CV} \%$ value, the finer the yarn. For this reason, Supima cotton is the smoothest yarn among these three types of yarns. While the Aegean cotton yarn has the highest value, the Giza cotton yarn has a value between the other two types of cotton.

It is seen that Supima cotton is superior when the number of thin and thick places are examined. Similarly, high values were observed in Aegean cotton yarns. The surfaces to be made from Supima cotton will produce a smoother appearance than the other yarns.

When the neps values are examined, the Supima cotton is seen to be advantageous. Neps, meaning small knots on the yarn surface, have a negative effect on the appearance and quality of the yarn.

When the hairiness values $(H)$ are examined, it is seen that Supima cotton has a lower value than Giza

\begin{tabular}{|c|c|c|c|c|}
\hline \multicolumn{5}{|c|}{ YARN PROPERTIES } \\
\hline Material & $\begin{array}{c}\text { Yarn } \\
\text { count } \\
\text { (Ne) }\end{array}$ & $\begin{array}{c}\text { Twist } \\
\text { coefficient }\end{array}$ & $\begin{array}{c}\text { Yarn } \\
\text { tensile } \\
\text { strength } \\
\text { (N) }\end{array}$ & $\begin{array}{c}\text { Yarn } \\
\text { breaking } \\
\text { elongation } \\
\text { (\%) }\end{array}$ \\
\hline $100 \%$ Aegean cotton & $60 / 1$ & $\alpha e=4$ & 1.3 & 3.9 \\
\hline $100 \%$ Giza cotton & $60 / 1$ & $\alpha e=4$ & 1.7 & 4.2 \\
\hline $100 \%$ Supima cotton & $60 / 1$ & $\alpha e=3.7$ & 1.9 & 4.6 \\
\hline
\end{tabular}

and Aegean Cotton. Since the Supima cotton contains extra-long fibers, the twist and the orientation of the fibers along the yarn will be good and the outgoing fiber ends will be less. This will result in less hairiness. This is a significant advantage.

Table 4 and table 5 shows the yarn and fabric properties used in the study, respectively.

Table 5

\begin{tabular}{|c|c|c|c|}
\hline \multicolumn{4}{|c|}{ FABRIC PROPERTIES } \\
\hline Material & $\begin{array}{c}\text { Weight } \\
\left(\mathbf{g} / \mathbf{m}^{\mathbf{2}}\right)\end{array}$ & $\begin{array}{c}\text { Thickness } \\
(\mathbf{m m})\end{array}$ & $\begin{array}{c}\text { Bursting } \\
\text { strength } \\
(\mathbf{k P a})\end{array}$ \\
\hline $100 \%$ Aegean cotton & 150 & 0.67 & 697 \\
\hline $100 \%$ Giza cotton & 150 & 0.63 & 813 \\
\hline $100 \%$ Supima cotton & 142 & 0.62 & 910 \\
\hline
\end{tabular}

The statistical significance of the difference between the tensile strength of the yarn and the bursting strength of the fabrics is shown in table 6 . When the tensile strength values of yarns were examined, it was determined that the strength of the yarns produced from Supima cotton was the highest and the yarns produced from Aegean cotton fibers were the lowest. Similarly, fabrics produced from Supima cotton yarns have the highest bursting strength. The difference between the tensile strength of the yarns and the bursting strength of the fabrics was found to be statistically significant (table 6).

Figures 1 and 2 show bursting strength and tensile strength.

Table 6

STATISTICAL SIGNIFICANCE LEVEL OF BURSTING STRENGTH OF FABRICS

\begin{tabular}{|c|c|c|}
\hline & Bursting strength & Tensile strength \\
\hline$p$ & $0^{*}$ & $0.015^{*}$ \\
\hline
\end{tabular}

${ }^{*} p<0.05$

Correlation analysis was carried out to determine the direction and strength of the relationship between the bursting strength of the fabrics knitted from the Supima cotton and the yarn tensile strength, the percentage of yarn extension, weight and thickness.

When table 7 is examined:

- It was determined that there was a high $(r=0.803)$, positive and significant relationship between the bursting strength of the fabric and the thickness of the fabric;

- It was determined that there was a high ( $r=0.867)$, positive and significant relationship between fabric bursting strength and fabric weight;

- It was determined that there was a high $(r=0.875)$, positive and significant relationship between the bursting 


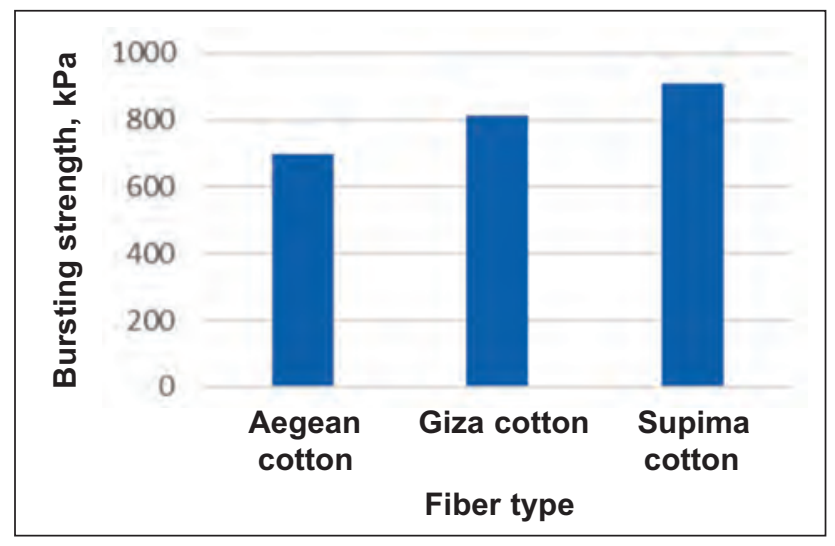

Fig. 1. Bursting strength values of fabrics

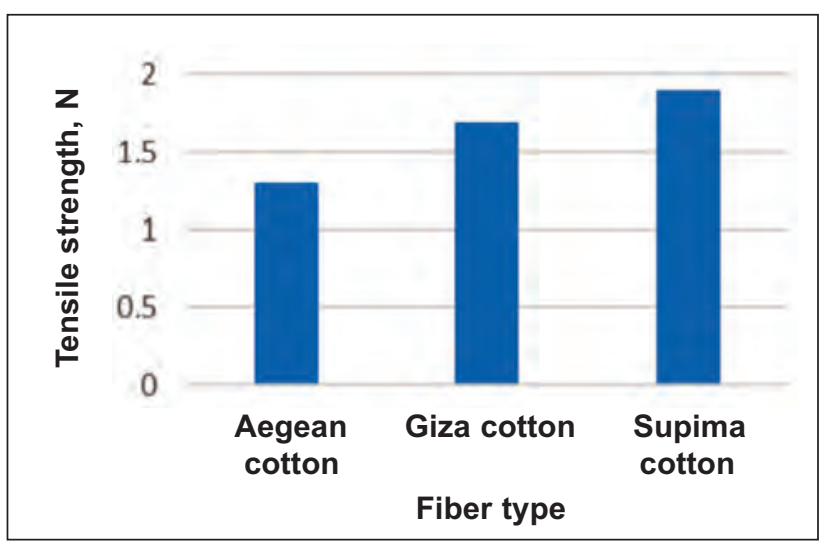

Fig. 2. Tensile strength values of yarns

\begin{tabular}{|l|c|c|c|c|c|}
\hline \multicolumn{6}{|c|}{ CORRELATION ANALYSIS OF FABRIC KNITTED FROM SUPIMA } \\
\hline \multicolumn{2}{|c|}{ Parameter } & Thickness & Weight & $\begin{array}{c}\text { Yarn tensile } \\
\text { strength }\end{array}$ & Elongation \\
\hline Bursting strength & Pearson Correlation $(r)$ & 0.803 & 0.867 & 0.93 & 0.875 \\
\hline
\end{tabular}

strength of the fabric and the percentage of yarn elongation;

- It was determined that there was a very high $(r=$ 0.93), positive and significant relationship between the bursting strength and tensile strength of the yarn.

According to the Pearson Correlation scale: $r ; 0-0.25$ very weak, $0.26-0.49$ weak, 0.50-0.69 medium, 0.70.89 high, $0.9-1.0$ very high.

Supima, Giza and Aegean Cotton rankings are formed when the bursting strength of the fabrics is ranked from high to low. Bursting strength depends on the yarn strength, yarn elongation, weight and thickness. Because of the highest tensile strength and elongation of the yarn in the knitted fabric from Supima, bursting strength of this fabric is highest. Supima fiber has extra long fiber properties. As a rule, the longer the fiber is the cotton fibers, the finer and the higher the strength. The strength of the yarn made of high strength fibers is also high.

\section{CONCLUSIONS}

Variation of fibers within wide limits in terms of fineness and length properties due to the uneven distribution of the fibers resulting from their random placement along the length of the yarn determin the number, strength, and twist properties of the yarn that change along the yarn. Irregularity in yarn is one of the most important factors affecting yarn quality in production, because the irregularities in the yarn cause the reduction of the yarn strength and the formation of thin-thick places. This causes the color unevenness in fabrics knitted with this yarn. The smoothness of the yarn depends on the raw material properties as well as on the quality of the processes that the raw material undergoes until it becomes a yarn. The yarn irregularity is expressed as a measure of how irregularly settled the fibers are in the yarn structure. The fineness and length of the fibers within the yarn structure is uniform, the yarn is so smooth and quality. When Uster results were examined, it was found that the yarn made of Supima cotton was the smoothest, low in hairiness and less neps. With these properties, the yarn breaks will be less, the image of the raw or the finished product will be more uniform. Low hairiness will also reduce the pilling tendency in the fabric.

According to the research results, the highest tensile strength of the yarns produced from Supima cotton, fabric weight and thickness are the lowest. Therefore, the bursting strength is higher than the other two materials. Supima cotton fiber has extra long fiber properties. As a rule, the longer the fiber is the cotton fibers, the finer and the higher the strength. The strength of the yarn made of high strength fibers is also high.

Considering the results obtained with the mechanical properties of the fabrics with Uster analysis applied to these yarns, it is seen that the yarns made from Supima and Giza cotton fibers in extra long fiber category have more smooth, less hairiness, contain less neps and the fabrics knitted with these yarns have high mechanical properties.

\section{ACKNOWLEDGEMENT}

This study was supported by Ege University Scientific Research Projects Coordination Unit. Project Number: 2016/BMYO/001. 


\section{REFERENCES}

[1] Erdumlu, N., Ozipek, B., Investigation of regenerated bamboo fibre and yarn characteristics, In: Fıbres \& Textiles in Eastern Europe, 2008, 16, 4 (69), 43-47

[2] Messiry, M., Abd-Ellatif, Samar, A.M., Characterization of Egyptian cotton fibres, Indian Journal of Fibre \& Textile Research, 2013, 38, 109-113

[3] Özçelik Kayseri, G., Bozdoğan, F., Hes, L., Performance properties of regenerated cellulose fiber, In: Tekstil ve Konfeksiyon, 2010, 20, 3, 208-212

[4] Demiröz Gün, A., Unal, C., Unal, B.T., Dimensional and physical properties of plain knitted fabrics made from 50/50 Bamboo/cotton blended yarns, In: Fibers and Polymers, 2008, 9, 5, 588-592

[5] Dirgar, E., The performance properties of the fabrics produced from cupro and some other regenerated cellulose fibers, In: Tekstil ve Konfeksiyon, 2017, 27, 2, 39-144

[6] Ozdemir, H., Effects of sizing and yarn structural properties on the physical properties of combed and carded cotton ring yarns, In: Industria Textila, 2018, 69, 2, http://doi.org/10.35530/IT.069.02.1329

[7] http://alpereniplik.com.tr/ege-pamugu, Date of access: 23.07.2018

[8] https://textilegence.com/supima-pamugu-hakkinda-sasirtici-5-gercek/, Date of access: 25.07.2018

[9] http://www.kirmeniplik.com/supima.html, Date of access: 23.07.2018

[10] https://tekstilsayfasi.blogspot.com/2013/01/misir-pamugu-nedir-ozellikleri.html, Date of access: 23.07.2018

[11] TS 7128 EN ISO 5084, Textiles-Determination of Thickness of Textiles and Textile Products, Turkish Standards Institution, Ankara, 1998

[12] TS 251, Determination of Mass per Unit Length and Mass per Unit Area, Turkish Standards Institution, Ankara, 1991

Authors:

\section{DIRGAR ESRA1 1 , ORAL OKSAN², OZDIL NILGUN}

${ }^{1}$ Ege University, Engineering Faculty, Textile Engineering Department Bornova 35100, Izmir, Turkey

${ }^{2}$ Ege University, Bergama Technical and Business College

Bergama 35700, Izmir, Turkey

e-mail: esra.dirgar@ege.edu.tr, oksan.kansoy@ege.edu.tr, nilgun.ozdil@ege.edu.tr

Corresponding author:

ORAL OKSAN

e-mail: oksan.kansoy@ege.edu.tr 